\title{
Constitutional Development in the Yukon Territory: Perspectives on the "Epp Letter"
}

\author{
STEVEN SMYTH ${ }^{1}$
}

\author{
(Received 11 February 1998; accepted in revised form 14 August 1998)
}

\begin{abstract}
The 1978 Yukon Territorial election was the first to be contested by all three territorial political parties. The Yukon Territorial Progressive Conservative Party, which won the election, quickly demanded constitutional change, and received a positive response from the federal Progressive Conservative government in 1979. The Minister of Indian and Northern Affairs, Jake Epp, acceded to the Yukon Government's request and issued a letter of instruction to the federally appointed Commissioner, Ione Christensen. He ordered her to divest herself of her portfolio responsibilities and not participate in executive decision making. Mrs. Christensen immediately resigned, stating that she did not want the role of a de facto Lieutenant Governor. Her resignation triggered a debate in the Yukon legislature and the media over whether the Territory was moving "too far, too fast" toward provincial status. Academics and politicians have also debated whether the changes effected by the "Epp letter" were significant and irreversible, or merely a "sop" to assuage local sentiments. The anomaly of the Yukon's constitutional status in Canada is raised as a consequence of this debate.
\end{abstract}

Key words: commissioner, constitution, directive, executive, federal, government, instructions, legislative assembly, media, minister, territory, Yukon

RÉSUMÉ. L'élection de 1978 dans le Territoire du Yukon a été la première à faire l'objet d'une contestation par les trois partis politiques du Territoire. Le parti Progressiste-Conservateur du Yukon, qui avait remporté l'élection, ne tarda pas à réclamer un changement constitutionnel et, en 1979, reçut une réponse positive du gouvernement fédéral Progressiste-Conservateur. Jake Epp, ministre des Affaires indiennes et du Nord canadien, accéda à la demande du gouvernement du Yukon et fit parvenir au Commissaire nommé par le fédéral, Ione Christensen, une lettre de directives. Il lui ordonnait de se défaire des responsabilités rattachées à son portefeuille et de ne pas participer aux prises de décision administratives. Madame Christensen démissionna immédiatement de son poste, déclarant qu'elle ne voulait pas d'un rôle de lieutenant-gouverneur de fait. Sa démission déclencha un débat à l'assemblée législative du Yukon et dans les médias sur le fait que le Territoire allait «trop tôt et trop vite» vers un statut de province. Les universitaires et les politiciens ont aussi débattu de l'importance et de l'irréversibilité réelles des changements amenés par la fameuse «lettre Epp» ou du fait qu'elle était tout simplement un énoncé de principes visant à calmer les esprits de la région. On soulève la question de l'anomalie du statut constitutionnel du Yukon au sein du Canada qui découle de ce débat.

Mots clés: commissaire, constitution, directives, administratif, fédéral, gouvernement, instructions, assemblée législative, médias, ministre, territoire, Yukon

Traduit pour la revue Arctic par Nésida Loyer.

\section{INTRODUCTION}

The 1970s were years of tremendous growth and change, political, economic, and constitutional, in the Circumpolar North. In Alaska, aboriginal land claims were settled and the Alaska pipeline was constructed, bringing financial independence to the state and a new era in aboriginal affairs. In Greenland, the people's struggle for constitutional change culminated in the granting of Home Rule in 1979. And the Inuit Circumpolar Conference was organized to promote Inuit interests internationally.

In the Canadian North, land claims were launched in the Yukon and Northwest Territories, and a settlement was quickly reached in northern Quebec in 1975 (The James Bay and Northern Quebec Agreement; see Morse, 1989:656). The Mackenzie Valley Pipeline Inquiry and the
Alaska Highway Pipeline Inquiry provided new opportunities for northern and aboriginal Canadians to express their concerns about development and, at the same time, fueled hopes for new jobs and economic development in the North.

In the Yukon, territorial constitutional development was a major political objective, and territorial politicians made rapid gains in several arenas: they obtained additional seats on the Executive Committee (cabinet), organized territorial political parties and ran candidates in territorial election campaigns. At least one federal party leader, Joe Clark, affirmed their aspirations for provincial status. In the land claims arena, the Council for Yukon Indians had launched its land claim and made significant progress at the negotiating table by 1978 . Both aboriginal and territorial leaders were jockeying for position with federal authorities, and clashes were inevitable. Minister

${ }^{1} 29$ Thompson Road, Whitehorse, Yukon Y1A 5R2, Canada

(C) The Arctic Institute of North America 
Faulkner described the situation succinctly in his letter of instruction to Commissioner Christensen on 25 January 1979:

I should emphasize that the three major matters which I have in mind-constitutional development, Indian land claims, and economic development (including pipelines _-all have a high degree of priority, and none of them can be pursued... at the expense of one or more of the others... The complexity of the linkages between these priorities is illustrated by the current constitutional situation in the Territory. The elected Territorial Council has been pressing for further transfers of authority...from the Federal Government. Yukon Indians, who have a direct relationship with the Federal Government,... have at the same time been pressing for greater authority...The requirement to reconcile the spirit and objectives of the Yukon and Indian Acts, as they relate to Government in the Yukon, poses a complex political problem for the Federal Government, and more particularly for me as the Minister responsible. (Faulkner, 1979).

The Yukon's Commissioner, a federal appointee, was expected to be a leader, a mediator, and a messenger, in an increasingly complex and hostile environment of party politics and land claim negotiations.

\section{BACKGROUND}

The Yukon Territory was created on 13 June 1898 with the passage of the Yukon Act (Yukon Act, [1898]). The Act provided for the appointment of a commissioner to be the chief executive officer of the territory and a council of up to six persons to assist the commissioner. This council became wholly elected in 1908, and was authorized to enact ordinances for the governance of the territory. In practice, the commissioner and his administration prepared all budgets and legislation, which were then presented to the council for ratification.

The Yukon Act requires the commissioner to administer the government of the Yukon under instructions given by the governor in council or the minister (Yukon Act, [1898]). Letters of instruction have often been issued by Ministers of Indian and Northern Affairs upon the appointment of a new Commissioner to provide overall guidance in the exercise of executive powers and, occasionally, to give specific direction on issues, such as refusal of assent to territorial legislation (Elliott, 1978; Smyth, 1988). Thus letters of instruction in the territories are important constitutional documents, which have no equivalent in the provinces. Furthermore, because instructions are specifically provided for in the Yukon Act, they may be considered a form of subordinate legislation. Lieutenant governors in the provinces, upon their appointment, are given overall guidance in their work by the governor in council. These instructions are pro forma documents, quite unlike the detailed and often specific instructions given to a territorial commissioner. Furthermore, instructions to lieutenant governors are authorized by their commissions, while instructions to commissioners are authorized by federal statute (Elliott, 1978).

\section{The Executive Committee}

In the late 1960s, members of the Yukon legislature vigorously lobbied the minister of Indian and Northern Affairs to form an executive council that would include elected members in the policy-making process. Minister Chretien eventually acquiesced to the appointment of a five-member executive committee (a proto-cabinet) consisting of the commissioner, two deputy commissioners, and two elected members. This committee was established by Commissioner James Smith under the authority of a letter of instruction issued on 17 June 1970 (Smyth, 1990).

The executive committee proved to be a valuable mechanism in the Yukon's constitutional evolution. Over the next eight years, the composition of the committee changed to reflect the growing influence of elected representatives: as additional elected members were appointed, nonelected appointees were dropped. Each change was sanctioned by a directive from the minister to the commissioner. The 1970 letter of instruction also required the commissioner to give "advice of Committee and especially elected members fullest possible consideration in determining the course of action to be followed by you in any given situation" (Chretien, 1970). Thus, the commissioner was to be guided by the advice of the committee, but was not required to follow it (Elliott, 1978). This was an irritant to the elected members, who by 1978 constituted a majority on the committee; they felt that it was undemocratic, colonial and anachronistic to have an appointed commissioner involved in policy-making. The situation in the Yukon was very different from that in the provinces, where the lieutenant governors had no role in policy-making and acted only on instructions from cabinet.

At the federal level, the Progressive Conservative and Liberal party leaders had quite different responses to Yukon's demands for rapid constitutional change. The Yukon's Member of Parliament, Erik Nielsen, a long-time advocate of provincial status for the Yukon, gained the support of Opposition leader Joe Clark for offering provincial status to the territory. Canada's Liberal prime minister, Pierre Trudeau, supported slower change, but discounted the possibility of provincial status "in my lifetime" (Whitehorse Star, July 12, 1976:1).

The territorial election of 20 November 1978 was the first to be contested by the territorial New Democratic, Liberal, and Progressive Conservative parties. The election was won by the Yukon Territorial Progressive Conservative Party, and the Yukon had, for the first time, a party-based government with a government leader equivalent to the premier in a province. This new political 
leadership soon demanded "full responsible government": that is, a fully elected executive committee responsible for all aspects of the administration of the Yukon Government. Minister Hugh Faulkner was sympathetic, and the appointment of a new commissioner, Ione Christensen, provided an opportunity to honour promises to grant additional responsibility to the elected members of the committee. Mrs. Christensen was the first lifelong resident of the Yukon to be appointed to this position.

\section{The Faulkner Letter}

Mrs. Christensen was initially invited to consider the appointment in August 1978, and was directly involved with senior Department of Indian Affairs and Northern Development (DIAND) officials in negotiating and drafting her initial letter of instruction, which set out the terms of reference for her position. She asked Minister Hugh Faulkner to review the proposed terms of reference with the new government leader, C.W. Pearson, and with the chairman of the Council for Yukon Indians, Harry Allen, before finalizing them. Faulkner acceded to the request, and Commissioner Christensen subsequently consented to her appointment (I. Christensen, pers. comm. 1998). This was the first time that territorial and aboriginal leaders had been consulted on the commissioner's instructions.

The minister's letter of instruction of 25 January 1979 stated that the responsibilities of the commissioner were to be divided into three categories: (1) areas where she was to be bound by the advice of the executive committee; (2) areas of federal and territorial interest that could be moved into Category 1; and (3) areas that would remain subject to federal direction. Category 1 matters included the preparation and introduction of bills and the administration of all ordinances passed by the commissioner in council except those included in categories 2 and 3. Category 2 matters included the following:

all Bills, Ordinances, policy decisions and administrative measures within the jurisdiction of the Commissioner under the Yukon Act as they affect the on-going federal interest with respect to: 1 . The rights and special interests of the Indian people of the Yukon... 2. Finance... 3. Territorial legislation administered by the Federal Government... 4. Responsibilities of the Commissioner for the general administration of the government. (Faulkner, 1979)

Category 3 items included all matters affecting the Yukon constitution: "These are principally the powers of the Commissioner and the Council, areas of territorial legislative jurisdiction and the relationship of the Territorial Government with departments and agencies of the Government of Canada" (Faulkner, 1979).

The letter outlined a further major change: the commissioner was to be bound by the advice of the government leader with respect to the names and number of elected members on the executive committee, instead of relying on nominations coming from the Yukon Council as a whole (Faulkner, 1979). This brought the Yukon's procedures into line with those of the provinces in determining the composition of the cabinet.

Faulkner's letter was important because it required the commissioner, for the first time, to accept the advice of the executive committee on some matters. Prior to this instruction, the commissioner was only required to give that advice "fullest possible consideration." However, the Faulkner letter did not come close to addressing the range or the magnitude of change sought by the Yukon Progressive Conservative Party's leadership, and relations between the new commissioner and the Conservative leadership were strained. Government Leader Pearson did not feel that it was appropriate for the commissioner to be involved in executive committee decision making, so the elected members of the committee met prior to full executive committee meetings to establish positions on policy issues and would refuse to accept any suggestions from the commissioner in full committee. Consequently, Mrs. Christensen had to either accept their decisions or veto them, and the latter course was not a palatable alternative: it would provide a platform for the government leader to challenge the legitimacy of having the commissioner on the committee and inflame federal-territorial relations (I. Christensen, pers. comm. 1998). The commissioner and deputy commissioner also held portfolio responsibilities in important areas (Finance, Public Service Commission, Executive Committee Office, Government Services, Intergovernmental Affairs, Liquor Corporation, and Workers' Compensation Board), and Mrs. Christensen felt that she could, and should, have a role in cabinet.

\section{The Political Situation}

Relations with the Council for Yukon Indians (CYI) were also strained early on. Commissioner Christensen supported a move to have the Yukon Government participate in land-claim negotiations as an independent third party, rather than as part of the federal negotiating team. When presented with a memorandum of understanding to give effect to this change in February 1979, she was strongly lobbied by CYI Chair Harry Allen not to sign (I. Christensen, pers. comm. 1998).

The federal election of May 1979 brought in the short-lived Progressive Conservative government of Joe Clark, and Jake Epp was appointed Minister of Indian and Northern Affairs. Shortly after the new minister's appointment on 4 June 1979, Yukon Government Leader Pearson presented the new minister with a letter outlining his government's position on obtaining a greater measure of responsible government for the territory. In his letter of 18 June 1979, Pearson specifically requested that the commissioner be removed from the executive committee and that the committee be renamed executive council, as was the practice in the provinces: 
it is our contention that the Commissioner need not and should not continue to play a predominant role in the day to day administration of the Yukon Government. The Commissioner's current portfolio of responsibilities should be transferred to elected members of the Executive Council. If these transfers were made, there would be little need for the Commissioner to chair or attend meetings of the Executive Council. In our view, the Commissioner should be directed to follow the same constitutional practices... as are followed in comparable situations by the Lieutenant-Governor of a province. (Pearson, 1979)

The letter also noted that Pearson had prepared draft terms of reference for the commissioner, as well as some suggested amendments to the Yukon Act for the minister's consideration. Pearson went on to suggest that "the establishment of a wholly elected Executive Council would also mean that the position of Deputy Commissioner would no longer be required. The Judge of the Supreme Court of the Yukon Territory could be appointed as Administrator pursuant to the Yukon Act during the Minister's absence, illness or other inability or when the office of Commissioner is vacant" (Pearson, 1979). The minister concurred with Mr. Pearson's views completely; however, he did not discuss Pearson's letter with Commissioner Christensen before issuing his letter of instruction to her. Instead, Mrs. Christensen was asked to review a draft position paper, dated 13 August 1979, on "Full Responsible Government." The paper, prepared by the Territorial Affairs Division of DIAND, proposed major and rapid changes, including removal of the commissioner from the executive committee and of her office from the territorial government building and new funding arrangements for the Yukon Government. Mrs. Christensen wrote to Minister Epp on 24 August 1979 to state that, while she did not oppose the changes categorically, she did feel that they would be implemented far too quickly for the fledgling Yukon Progressive Conservative Party government to absorb. She also felt they could jeopardize land-claim negotiations (I. Christensen, pers. comm. 1998). Her view conflicted with the aspirations of the Yukon Government's leaders, who were advocating rapid change.

Pearson's proposals for change were revealed to the public by Opposition Leader Iain MacKay at a press conference on 18 July 1979. And in September, Commissioner Christensen publicly announced that she might resign if her role in government were substantially reduced (Smyth, 1991).

\section{THE EPP LETTER}

In his 9 October 1979 letter to Commissioner Christensen, Minister Epp instructed her to:

request the Territorial Government Leader that he shall constitute and appoint a body known as the Cabinet or the Executive Council which will have as its members those elected representatives of the Territorial Council who are designated from time to time by the Government Leader who enjoys the confidence of the Council. On the advice of the Government Leader you shall assign Department executive responsibilities to the appropriate members of the Executive Council.

He went on to instruct her to remove herself from the policy-making process: "You will not be a member of the Cabinet or the Executive Council, and will not participate on a day-to-day basis in the affairs of the Cabinet or the Executive Council, and Council of the Yukon in those matters delegated in the Yukon Act to the Commissioner in Council" (Epp, 1979). He also stated: "I hereby instruct you to accept the advice of the Council in all matters in the said [Yukon] Act which are delegated to the Commissioner in Council, provided that those matters meet the requirements of Section 17 of the said Act and excepting Section 46 of the said Act" (Epp, 1979). (Section 17 stated that the powers to legislate could not exceed those granted to provinces, while Section 46 specified that all lands in the Yukon remain vested in Her Majesty in right of Canada.) Thus the commissioner was required to take on the role of a de facto lieutenant governor for the Yukon: she would no longer hold a portfolio of ministerial responsibilities or be a member of cabinet, and would accept the advice of the government leader on all policy and legislative matters. Other consequences of the Epp letter were the dismissal of the deputy commissioner, Douglas Bell (although he stayed on as the Yukon's administrator) and the authorization for the government leader to refer to himself as "Premier" and to his cabinet members as "Ministers" if they so wished. Cabinet documents such as "Commissioner's Orders" became "Orders-In-Council" and "Records of Recommendation" were renamed "Records of Decision," to reflect the fact that the cabinet had replaced the commissioner as the ultimate decision-making authority in the territory.

The changes effected by the Epp Letter brought the Yukon suddenly into line with the practices and procedures familiar to most Canadians from provincial governments: elected representatives of the people of the territory could now be held fully accountable for the policies, priorities, and expenditures of the Yukon government. There were no longer any federal appointees involved in executive decision making or holding portfolio responsibilities in the Yukon government.

\section{REVOLUTION OR EVOLUTION?}

Events on 9 October 1979 unfolded rapidly and dramatically. At about 9:30 a.m., Indian and Northern Affairs Minister Jake Epp held a telephone press conference with local reporters to discuss the contents of his letter. He confirmed his intention to amend the Yukon Act after meeting with elected representatives of the Yukon 
Government and Council for Yukon Indians to discuss constitutional change (Senger, 1981). Epp also reiterated the prime minister's election promise that Yukon residents would be given an opportunity to vote on provincial status in a referendum to be held during the government's first four years in office:

What we intend to do, as I indicated again: the prime minister indicated during the election campaign, was to establish responsible government whereby all people of Yukon could participate. Once that had been done, then the decision could be taken on whether or not a provincial status was in the best interest of Yukoners and I have indicated very clearly that that will be done by referendum, by the citizens of Yukon. (Senger, 1981)

Mrs. Christensen, having reviewed her new terms of reference, quickly decided that she was not prepared to be a quasi lieutenant governor. She phoned the minister's office that afternoon to tender her resignation: "I phoned the Minister at about 2:45, or the Minister phoned me...he returned my call... and I told him at that time that with deep regrets I felt I would have to tender my resignation immediately...that the terms of reference were not the terms of reference that I could work with" (Senger, 1981). This decision was also communicated to Government Leader Chris Pearson, who was speaking in the Second Session of the 24th Legislature. He interrupted his speech to announce:

Now, Mr. Speaker, I have an announcement to make which I regret very much. In a letter to the Minister of Indian Affairs and Northern Development, on June 18th, 1979, and in subsequent meetings with the Minister, the Government of Yukon outlined some positive measures to further the evolution of responsible government in Yukon.

Although I am pleased to report that the Minister has responded favourably to our requests, it is with considerable regret that my colleagues and I have learned of Commissioner Christensen's intention to resign. I would like to stress that we have the greatest regard for Commissioner Christensen and would have liked very much to have had her continue as the functions of the office are changed.

Mrs. Christensen has performed her duties as Commissioner with diligence and dignity. Her decision to resign is most unfortunate in view of the vital role she has already played in contributing to the development and success of responsible government in Yukon. (Government of Yukon, Hansard, 9 October 1979:337)

Mrs. Christensen held a press conference at 4:00 p.m. to elaborate on her reasons for resigning. In her words:

In using the terms of reference I see really two very distinct roles: two roles that I feel are not compatible or can[not] be played by only one person. I see the role of Lieutenant-Governor, although it is not spelled out as Lieutenant-Governor, but quite obviously that is the role.....and I see the other role... and that is the role I do not feel has been addressed or clarified...the terms of reference state what the commissioner will not do. I do not think they spell out what the commissioner shall do ...that has been alluded to, but it has not been spelled out and I think it should have been spelled out more clearly. (Senger, 1981)

In the Yukon Legislative Assembly, Opposition Leader Iain MacKay spearheaded questions about the government's agenda in pushing for constitutional change. He viewed the Epp letter as making the Yukon a de facto province:

That search for power has been a Holy Grail for successive Executive Committees, the goal being, ultimately, provincial status. Well, if that is the goal, I think I should congratulate the Members opposite, because I think that, in fact, you have achieved de facto provincial status with that letter today. (Government of Yukon, Hansard, 9 October 1979:344)

MacKay went on to decry the changes on the basis that they had not been adequately considered or opened to public discussion:

I will say that the essential preconditions to provincial status should have been a study of the costs of this move, who is paying the bills now, who will do it next year and the year after that. There should have been open and public negotiations with the Federal Government on these things. There should have been a settlement of Indian Land Claims. There should have been a study of the institutions and manpower and talent requirements of a province.

There should have been a clear question in a referendum. None of this happened. Instead, I think, I have not heard her reasons yet, but we have heard of the resignation of the Commissioner. She has stated publically before today that such an event could occur. (Government of Yukon, Hansard, 9 October 1979:345)

On 15 October, the executive of the Council for Yukon Indians re-entered the debate by flying to Ottawa to demand that constitutional issues be included in the land claims forum. This resulted in a further meeting on 25 October involving Yukon government, Council for Yukon Indians representatives, and the minister of Indian and Northern Affairs. By 21 November, Yukon government officials were able to confirm that they concurred with this approach (Smyth, 1991:63).

In the interim, the debate continued in the media and the Yukon Legislative Assembly. On 17 October, the local 
Canadian Broadcasting Corporation station sponsored a radio debate on Yukon constitutional development entitled "Too Far, Too Fast?" In the Legislative Assembly, the New Democratic Party member, Tony Penikett, brought forward Motion Number 30, which proposed the creation of a special committee on constitutional development to hear from the public and discuss Yukon's constitutional development (Government of Yukon, Hansard, 17 October 1979:541-542).

The motion was supported by both the government and opposition parties, and thus provided some measure of resolution to the debate. However, the Committee's work was eclipsed by the defeat of the Clark government and the calling of a federal election for 18 February 1980.

Former Commissioner Christensen contested the riding for the Liberal Party and was only narrowly defeated by incumbent, Erik Nielsen. Nonetheless, the Liberals were granted a majority government, and the new minister, John Munro, announced on 29 October 1980 that there would be no further changes to the Commissioner's letter of instructions (Smyth, 1991).

\section{THE SIGNIFICANCE OF THE LETTER}

The significance of the Epp letter to the Yukon's constitutional development has been a matter of some debate. At one extreme would be Erik Nielsen's perspective that it was merely a "sop" to the Yukon political leadership and carries no significance because the changes were never enshrined in federal legislation. Nielsen does not even mention the Epp letter in his autobiography, The House is Not a Home (Nielsen, 1989), and in a public forum held in Whitehorse on 20 July 1995, he stated:

Suffice it to say, that the Epp letter is just that-and nothing more-in my opinion....In my opinion the Epp letter was a sop. The Epp letter was the degree to which the bureaucracy was prepared to meet the rising tide of frustration and resentment in the Yukon with respect to the lack of any representation at the grass roots. It was not enough for me. I wanted to go much further....There is no legislative force to the Epp letter. (Nielsen, 1995)

Nielsen is certainly correct that ministerial letters of instruction can be much more easily amended or revoked than amendments to federal legislation. The federal government has been reluctant to address amendments to the Yukon Act, except on issues of significance to the federal government. The time and effort required to get items onto the government's legislative agenda are significant, while instructions to commissioners are relatively easy to effect and can presumably be accomplished without even taking the matter to cabinet. Nielsen's disappointment can perhaps be attributed in large measure to the fact that the Conservative government did not have sufficient time before it was defeated to amend the Yukon Act, which would have given the Epp letter the permanence he sought. However, it is understating the importance of letters of instruction to suggest that they have no legislative force: they at least have status as subordinate legislation. And the fact that the Epp letter has only been elaborated upon, and never revoked, gives some credence to the argument that it now has a measure of permanence, perhaps even the recognition of being a convention.

Yukon historian Brent Slobodin argues that the changes formalized in the Epp letter are politically irreversible. According to this perspective, it would not be possible to change the commissioner's terms of reference to return the commissioner to a decision-making role on the executive:

Nielsen is quite wrong in saying that it could all be taken away by the federal minister. Given the evolutionary growth away from Britain of Canada itself, the precedents are such that the Supreme Court would not support it. I can only see Ottawa doing such a thing if the territory became broke and found itself unable to generate sufficient revenue. (B. Slobodin, pers. comm. 1998)

The strength of this argument may well be that political executives in Canada need not have a legislative or constitutional basis in statutes: they exist because elected members of political parties recognize the authority of their leaders to appoint cabinets and organize the operations of government. The governor general and lieutenant governors, while holding formal executive authority in law, are powerless except in exceptional circumstances. Consequently, any attempt to return the commissioner to cabinet by amending the letter of instruction would be viewed as fundamentally undemocratic, and thus illegitimate, by the people of the Yukon and Canadians generally.

Kirk Cameron and Graham White, authors of Northern Governments in Transition, appear to side with Nielsen in this debate. They suggest that the Epp letter may represent little more than political opportunism:

The Epp letter has been criticized as a master stroke of political opportunism, the main purpose of which was to promote the Progressive Conservatives as the party of economic and political progress in the North. Since responsible government, according to this view, had effectively been achieved under the Liberals, the Epp letter was essentially a public relations exercise rather than a genuine constitutional advance. The accuracy of this interpretation is a matter for debate; what is not at issue is that the Epp letter, by formally recognizing the establishment of responsible government, signifies the culmination of the changes occurring during the previous decade. (Cameron and White, 1995:23)

Furthermore, Cameron and White (1995) suggest that while the territories have developed a unique constitutional 
status because of land-claim agreements and certain court decisions, they might still be subject to ministerial fiat:

the Territories remain vulnerable to external actions that could affect their ability to determine their evolution. Their territorial constitutions...leave the federal minister responsible for the North with substantial power to modify the relationship between the Commissioner, the executive and the assembly.

If...conventions are clearly developing in the territories, as yet no test-political or legal—has confirmed the inviolability of the current government structure or whether the federal minister is restricted in exercising control over the commissioners. (p. 122-123).

Consequently, they argue that the territories' constitutional progress to date needs to be protected through amendments to the territorial constitutions and to the Constitution of Canada (Cameron and White, 1995). Nielsen would concur.

Cameron and Gomme (1991) also note the argument made by Professor Cheffins that conventions are easily dispensed with by written law:

Conventions, the Court stated, are not enforced by the Courts; where there is explicit legislation granting authority, that legislation can be amended whenever deemed appropriate by the government which passed it; and therefore, given the status of the Yukon Act as a piece of federal legislation, Parliament may amend that statute as and when it sees fit. (Cameron and Gomme, 1991:7)

Cameron and White's perspective is supported and well stated by the federal government's most recent, although now dated, policy statement on northern development, A Northern Political and Economic Framework:

The acts say nothing of an executive council whose advice must be taken and suggests [sic] a comprehensive capacity for ministerial control. Instructions from the minister to the commissioners and nothing more enduring set out the system of administering the powers of the territorial governments. Furthermore, all territorial legislation is automatically subject to federal legislation and the powers of reservation and disallowance. While it has been suggested the territories already have responsible government by virtue of customary usage and convention, the fact remains that the federal government is ultimately responsible in law for the action of the territorial executive. More specifically, while the powers of reservation and disallowance have not been imposed, there are nevertheless robust prerogatives which could be exercised by the minister and the governor-in-council at any time. (Government of Canada, 1988:7)

Gurston Dacks' perspective on the Epp letter was that its impact was more than symbolic. He viewed the letter's role as crucial in transferring accountability for budgetary matters to elected representatives:

In October 1979, Mr. Faulkner's Conservative successor, Jake Epp, went substantially farther by transferring ultimate executive responsibility from the Commissioner to the Territorial Legislative Assembly acting through what was now called its Executive Council. The Commissioner was no longer to sit on the Executive Council, whose members were not only individually responsible for their departments but also collectively [responsible] for the territorial budget. This was a crucial grant of power, given that the budget is the basic device used by governments to determine their priorities. (Dacks, 1981:91-92)

While this latter perspective is persuasive, it does not address the issue of the permanence of the change effected. The fundamental issues, the constitutional status of the Yukon and the federal government's role in governing the territory, remain unresolved.

\section{The Yukon's Constitutional Status}

The use of letters of instruction and the question of their permanence raise the issue of the Yukon's subordinate status in Confederation. Other examples of the Yukon's subordinate status, as compared with provinces, include the reservation of assent to the executive council bill by the Yukon's Administrator, upon the instructions of the minister, in 1982; the transfer of land in the Yukon to the ownership of the Tetlit Gwitch'in people of the Northwest Territories (over the objections of the Yukon government) in 1992; and the amendments to the Constitution Act (1982) that imposed paragraphs 42(1) (e) and (f) on the territorial governments. These amendments authorized the federal government, with the consent of seven provinces, to amend territorial boundaries or grant provincial status. Prior to 1982, the federal government alone could have granted provincial status. Thus, the people of the territories continue to live with constitutional uncertainty that other Canadians do not face. The federal government, with the collusion of seven provinces, has the ability to amend the Yukon's constitutional arrangements without the consent of the Yukon's people. It can unilaterally veto territorial legislation by ministerial directive. Furthermore, under the current constitutional amending formula (42 (1) (e) and (f) of the Constitution Act), it can thwart attempts to attain provincial status (even if seven provinces approved provincial status, the federal government could veto it by not proceeding with a resolution in Parliament) and alter territorial boundaries without the consent of Yukon residents. These are not actions that most Canadians would accept as legitimate today. Consequently, the constitutional status of the territories remains an issue which should concern Canadians, given our expectation that all Canadians have equality under the law. 


\section{CONCLUSION}

This paper is about the constitutional development of the Yukon Territory and the importance of the Epp letter to that development. The Epp letter was an important document because it brought about a fundamental change to the executive of the Yukon government: the federally appointed commissioner was instructed to let elected representatives take full responsibility for all budgetary and policy issues in the Yukon. This was the final stage in a nine-year process that gradually reduced the influence of federally appointed officials on the policy making of the Yukon government.

It is possible that the Epp letter was unnecessary: elected representatives might have displaced the commissioner from cabinet by meeting on their own, making their own decisions, and launching their own initiatives in the legislative assembly, without ever consulting the commissioner. This was the course they were on before the issuance of the Epp letter. It would have been a difficult fight, however: as long as the commissioner and deputy commissioner held portfolio responsibilities for Finance and other important departments, efforts to circumvent the commissioner might have been stymied. The commissioner's role as mediator would certainly have been sorely tested. A sympathetic federal minister forestalled an open confrontation between the elected cabinet ministers and the commissioner by instructing the commissioner to leave the cabinet room altogether. A different government and a different minister might have reacted differently.

A fundamental question remains: to what extent can the minister of Indian and Northern Affairs intervene in the governance of the Yukon by using the power of instruction granted under the Yukon Act? Could the minister restore the commissioner to Yukon's cabinet if the territorial economy suffered a severe setback and its population dwindled? What are the limits on the federal prerogative in the North? And, ultimately, why should northern Canadians live under a constitutional regime that permits these powers to be exercised and that differs so much from the constitutional arrangements of provinces? The resolution of these questions must come about, as suggested by Nielsen and by Cameron and White, through legislative change that places northern Canadians on an equal footing with all other Canadians. At minimum, the minister's prerogative of issuing instructions to the commissioner should be repealed. A provincial government would not accept a federal minister's meddling in the affairs of its executive, and constitutional conventions now provide sufficient direction to commissioners in their conduct of public affairs. Indeed, the most recent directive from DIAND Minister Jane Stewart (Stewart, 1997) to Commissioner Judy Gingell instructed her as follows:

There have been instances in Yukon's history when former Commissioners have had to exercise discretion in respect to elections. In such situations, you are to follow conventions and traditions as they have emerged in Canada relative to the offices of the Governor General and provincial Lieutenant Governors.

With regard to situations where you are called upon to sign documents on behalf of the Government of the Yukon, in all matters where the Yukon Legislative Assembly and the Yukon Government have responsibility, you will accept the recommendations of your first minister. (Stewart, 1997)

If federal intentions to foster constitutional development in the North are to be credible, actions to demonstrate those intentions will speak louder than words. In the Yukon, this will mean replacing directives with conventions and changing legislation to support constitutional development.

\section{REFERENCES}

CAMERON, K., and GOMME, G. 1991. The Yukon's constitutional foundations. Vol. 2: A compendium of documents relating to the constitutional development of the Yukon Territory. Whitehorse: Northern Directories Ltd. 332 p.

CAMERON, K., and WHITE, G. 1995. Northern governments in transition. Montreal: Institute for Research on Public Policy. $151 \mathrm{p}$.

CHRETIEN, J. 1970. Telex to Commissioner James Smith, 17 June 1970.

DACKS, G. 1981. A choice of futures: Politics in the Canadian North. Toronto: Methuen. 226 p.

ELLIOTT, D.W. 1978. Some constitutional aspects of the government of the Yukon Territory. Whitehorse: Government of Yukon. 241 p.

EPP, J. 1979. Letter to Commissioner Christensen, 9 October 1979.

FAULKNER, H.J. 1979. Letter to Commissioner Christensen, 25 January 1979.

GOVERNMENT OF CANADA, 1988. A northern political and economic framework. Ottawa: Department of Indian and Northern Affairs.

GOVERNMENT OF YUKON, 1979. Hansard. Available from the Department of Government Services, Government of Yukon, Box 2703, Whitehorse, Yukon, Y1A 2C6, Canada.

MORSE, B.W. 1989. Aboriginal peoples and the law: Indian, Metis, and Inuit rights in Canada. Ottawa: Carleton University Press. 981 p.

NIELSEN, E. 1989. The House is not a home. Toronto: Macmillan.

1995. Speech to the Institute of Public Administration/ Yukon Historical and Museums Association. Whitehorse, Yukon, 20 July 1995.

PEARSON, C.W. 1979. Letter to Minister Epp, 18 June 1979.

SENGER, D. 1981. Selected readings on the creation of the Yukon Executive Council, October, 1979. Whitehorse: Government of Yukon, Executive Council Office. 
SMYTH, S. 1990. Ministerial directives and constitutional development in the Yukon Territory. The Polar Record, 26(156):7-12.

1991. The Yukon's constitutional foundations. Vol. 1: The Yukon chronology. Whitehorse: Northern Directories Ltd. 263 p.
STEWART, J. 1997. Letter to Commissioner Judy Gingell, 28 August 1997.

[YUKON ACT] The Yukon Territory Act [1898]. The Revised Statutes of Canada, 1985. c. Y-2, s. 1. Ottawa: Supply and Services Canada. 